\title{
O AVANÇO DA BIOLOGIA MOLECULAR EM CASOS DE SEVERA ATROFIA DOS MAXILARES UTILIZANDO A rhBMP-2
}

Rafaela LARSON, Sahara LITTIERI, André ZÉTOLA

Atualmente a utilização da proteína morfogenética recombinante sintética do tipo 2 (rhBMP-2) esta sendo indicada em casos onde o defeito ósseo necessita de enxertia, como em maxilares atróficos, substituindo materiais como crista ilíaca, calota craniana e banco de ossos. O caso a ser relatado demonstra a utilização da rhBMP-2 associada a esponja de colágeno (ACS) a qual induz por si própria a formação óssea[BOYNE et al,2007]. Aqui, a proteína foi utilizada em conjunto com outros materiais como osso cerâmico e membranas de colágeno, possibilitando a neoformaçao óssea na pré-maxila. A reabilitação com implantes foi realizada posteriormente, alguns de carga imediata e então a instalação de uma prótese tipo overdenture. $O$ método utilizado neste estudo demonstrou capacidade de induzir a formação de osso em um sítio ectópico, apresentando resultados satisfatórios em casos de reconstruções maiores[AROSARENA, 2005]. Assim como qualquer material utilizado para enxertia, a BMP deve ser utilizada em um leito receptor bem preparado, vascularizado, com ausência de drenagem e secreção purulenta. Não foram observados quaisquer efeitos tóxicos ou de caráter carcinogênico e imunogenico na utilização da rhBMP-2.

Palavras-chave: enxertia, formação óssea, reabilitação. 